\title{
Lavado peritoneal em um caso de rompimento de abomaso em bovino
}

Ronaldo Alves Martins;, Valentim Arabicano Gheller, Philipe Pimenta Nunes, João Paulo Andrade, Rodrigo Melo Meneses, Antônio Último de Carvalho, Elias Jorge Facury Filho

Universidade Federal de Minas Gerais (UFMG), Belo Horizonte, MG, Brasil

*Autor correspondente

e-mail: ronaldo_martinsvet@yahoo.com.br

\section{Resumo}

O deslocamento de abomaso é uma doença frequentemente relatada em rebanhos de bovinos leiteiros, tendo incidência que varia de 0 a 20\% em rebanhos de exploração leiteira. Pode ser classificada pelo movimento que o abomaso faz durante o deslocamento, sendo mais comumente classificado como deslocamento de abomaso à direita e deslocamento de abomaso à esquerda. Foi atendido um animal no Hospital Veterinário da Escola de Medicina Veterinária da UFMG. Uma laparotomia foi realizada no dia 17/05/13, onde se pôde perceber que a porção ventral do abomaso estava aderida ao peritônio na porção próxima ao esterno. No momento de manipular para reposicionar o abomaso na região anatômica, o mesmo se rompeu em três regiões, pois estava friável e apresentando várias úlceras. Foi realizada abomasorafia e lavagem abdominal com 16 litros de solução de soro fisiológico ( $\mathrm{NaCl}$ 0,9\%) em solução com gentamicina ( $4 \mathrm{mg} / \mathrm{kg}$ ). Foi colocado um cateter de Foley número 24 na incisão cirúrgica, e outro na região ventral próximo à cicatriz umbilical, com auxílio de um trocáter, ambos os cateteres fixados na pele com fio de nylon. Durante cinco dias consecutivos foram infudidos 20 litros de água destilada juntamente com Gentamicina (4 mg/kg). No momento da lavagem eram infundidos aproximadamente 10 litros da solução pelo cateter da incisão cirúrgica e movimentava-se o animal para melhor dispersão da solução no abdômen; em seguida, abria-se o cateter ventral onde tinha um fluxo contínuo de líquido. Nos primeiros lavados, o líquido tinha aspecto turvo, com grande presença de espuma, e coagulava com aspecto gelatinoso, sugerindo presença de proteínas e fibrina. Com o passar dos dias o líquido se tornou mais límpido e com menos presença de fibrina. Como tratamento suporte foram aplicados Flunixim Meglumine (2,2 mg/Kg) durante três dias, Penicilina (50.000 UI/Kg) durante cinco dias por via intramuscular profunda, e omeprazol ( $4 \mathrm{mg} / \mathrm{Kg}$ ) oral por 28 dias. No dia seguinte à primeira lavagem preitonial (18/05/13) houve um episódio de hemoglobinúria, sem febre e sem hemoparaitas diagnosticados em esfregaço sanguíneo. 0 animal se manteve prostado, apresentando anorexia e adpsia. No segundo dia 
pós-cirúrgico, o animal começou a se alimentar com capim picado. A medida que o apetite foi aumentando, foi introduzido à dieta feno, silagem de milho e concentrado comercial para bovinos. No quinto dia póscirúrgico, os cateteres foram retirados. No dia 06/06/13, o animal recebeu alta e retornou para a fazenda de origem. A lavagem peritoneal em bovinos é pouco utilizada, principalmente pelo grande volume de solução a ser utilizada. No entanto, no caso citado foi utilizada como conduta médica que teve resultado positivo e com baixo custo, sendo um importante adjuvante à terapêutica estabelecida para restabelecimento clínico cirúrgico do animal. 